\title{
ENDOMETRIAL HYPERPLASIA DUE TO GRANULOSA CELL TUMOUR PRESENTING WITH MENORRHAGIA: CASE REPORT
}

\author{
Kanwardeep Kaur Tiwanaํㅜ, Sarita Nibhoria², Manmeet Kaur ${ }^{3}$, Richa Phutela ${ }^{4}$
}

\section{HOW TO CITE THIS ARTICLE:}

Kanwardeep Kaur Tiwana, Sarita Nibhoria, Manmeet Kaur, Richa Phutela. "Endometrial Hyperplasia due to Granulosa Cell Tumour Presenting with Menorrhagia: Case Report". Journal of Evolution of Medical and Dental Sciences 2014; Vol. 3, Issue 17, April 28; Page: 4718-4720, DOI: 10.14260/jemds/2014/2501

\begin{abstract}
A 55 year old patient present with menorrhagia. Endometrial biopsy was done revealing hyperplasia of endometrium following which total abdominal hysterectomy with bilateral oophorectomy was carried out to rule out any hidden focus of endometrial malignancy. The histopathology revealed simple endometrial hyperplasia with microscopic focus of granulosa cell tumour in the right ovary. We in this case report are highlighting importance of screening of ovarian tumour in perimenopausal patients presenting with menorrhagia.
\end{abstract}

KEYWORDS: Endometrial hyperplasia, Granulosa cell tumour, Menorrhagia.

INTRODUCTION: Postmenopausal bleeding is very uncommon clinical presentation in ovarian tumours. Sex cord stromal tumours are the most common functional tumours of ovary. ${ }^{1}$ Hyperestrogenism is commonly caused by granulosa cell tumour and thecomas, whereas patients with sertoli-leydig cell tumours manifest hyperandogenism. However granulosa cell tumour are rare, accounting for only $2-3 \%$ of ovarian malignancies. ${ }^{2}$ It constitutes one of the rare causes of delayed menopause. In this case report we are highlighting granulosa cell tumour in normal appearing ovary in perimenopausal patient having endometrial hyperplasia presenting with menorrhagia.

CASE REPORT: A 55 year old patient presented with menorrhagia. On examination uterus was bulky and on ultrasonography increased endometrial thickness was seen, but the adnexa was normal. Endometrial biopsy was performed and on histopathology simple hyperplasia of endometrium was reported. Total abdominal hysterectomy with bilateral salpingo-oophorectomy was performed. Histopathological examination of hysterectomy was done and endometrium showed simple hyperplasia and granulosa cell tumour was seen in right ovary and other ovary was normal. Immunohistochemistry was positive for inhibin.

DISCUSSION: Granulosa cell tumour is the most common malignant sex cord-stromal tumour, accounting for $70 \%$ of all sex cord-stromal tumours.2,3 But Granulosa cell tumour is a rare neoplasm accounting for approximately 1.5-3\% of all ovarian malignancies. ${ }^{4}$ They are of two types juvenile [5\%] or of the adult type [95\%]. In adult granulosa cell tumour the most common endocrine manifestation in the perimenopausal and menopausal age group is abnormal uterine bleeding and the most common presentation is endometrial hyperplasia $[50 \%]^{5}$ and another $8-33 \%$ have endometrial adenocarcinoma.

In this case we are highlighting that granulosa cell tumour could be cause of dysfunctional uterine bleeding hence importance must be given to accurate imaging and histopathological examination of ovaries. Majority of granulosa cell tumours are unilateral and on sonogarphy appear as round to ovoid masses that are multicystic with solid areas. ${ }^{6}$ Microscopically granulosa cell 
tumours are composed of granulosa cells, theca cells and fibroblasts and they exhibit various patterns like microfollicular, macrofollicular, trabecular and insular. The microfollicular pattern is characterized by the presence of Call-Exner bodies. The granulosa cells have scant cytoplasm and round to ovoid nucleus with longitudinal groove. They are immunoreactive for inhibin.

Granulosa cell tumours have a low malignant potential and have good prognosis. There are various factors which are helpful in predicting survival. Chan et al, found age<50years, small tumour size and absence of residual disease are prognostic factors. ${ }^{5}$ Patient need to be made aware about the need for long term follow up despite of relative indolent nature, late recurrences are seen. ${ }^{7}$

In this case report we are highlighting the fact that granulosa cell tumour is one of the rare tumours of ovary but any patient presenting with perimenopausal menorrhagia the possibility of granulosa cell tumour must be kept in mind. Early diagnosis and treatment is key for prolonged survival in this age group.

\section{REFERENCES:}

1. Williams SD, Gershenson DM. Management of germ-cell tumours of the ovary. In: Cancer of the ovary New York, NY: Raven, 1993; 375-384.

2. Van Holsbeke C, Domali E, Holland TK et al. Imaging of gynecological disease. III. Clinical and ultrasound characteristics of granulosa cell tumours of the ovary. Ultrasound Obstet Gynecol 2008; 31(4): 450-456.

3. Malmstrom H, Hogberg T, Risberg B, Simonsen E. Granulosa cell tumours of the ovary: prognostic factors and outcome. Gynecol Oncol 1994; 52(1):50-55.

4. Pectasides D, Pectasides E, Psyrri A. Granulosa cell tumour of the ovary. Cancer Treat Rev 2008; 34: 112.

5. Chang JK, Zhang M, Kaleb V, Loizzi V, Benjamin J, Vasilev S, et al. Prognostic factors responsible for survival in sex cord stromal tumours of the ovary-a multivariate analysis. Gynecol Oncol 2005; 96: 2049.

6. Sharony R, Aniram R, Fishman A, Cohen I, Altaras M, Beyth Y et al. Granulosa cell tumours of the ovary: Do they have any unique ultrasonographic and color doppler flow features? Int J Gynecol Cancer 2001; 11: 22933.

7. Kondi-Pafiti A, Grapsa D, Kairi-Vassilaton E, Carvounis E, Hasiakos D, Kontogianni K et al. Granulosa cell tumours of the ovary: A clinicopathological and immunohistochemical study of 21 cases: Eur J Gynecol Oncol 2010;31: 948. 


\section{CASE REPORT}

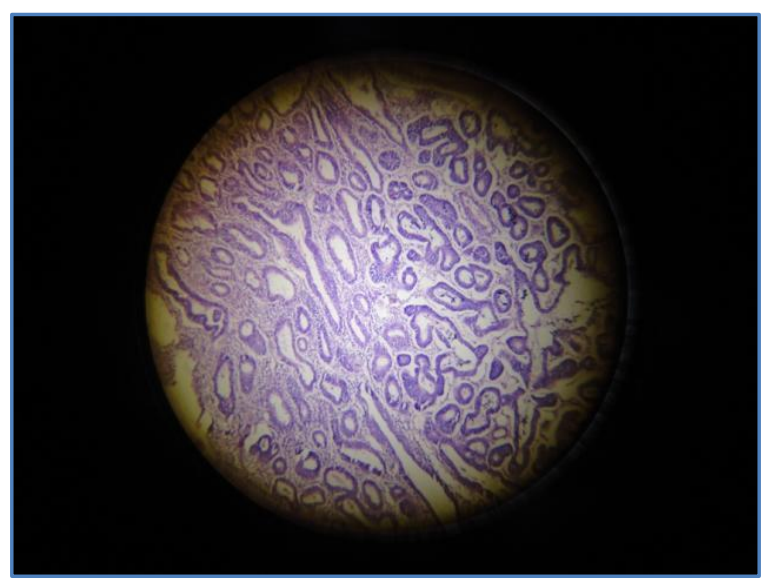

Figure 1

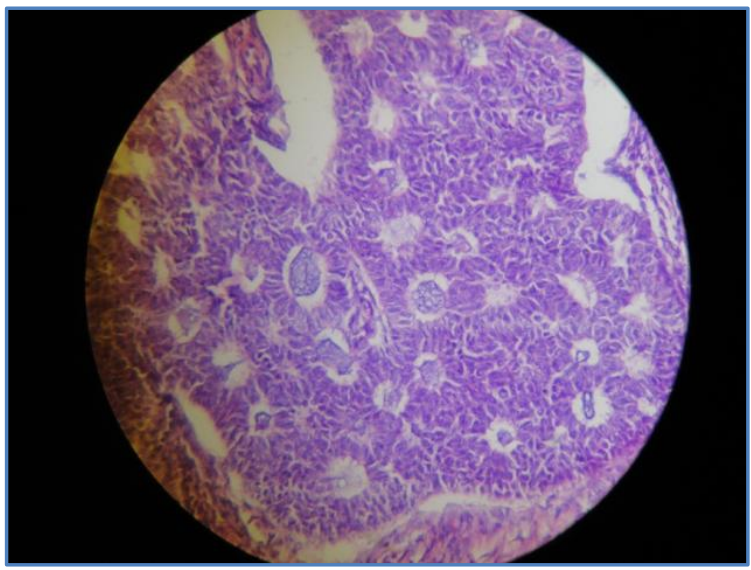

Figure 2

\section{AUTHORS:}

1. Kanwardeep Kaur Tiwana

2. Sarita Nibhoria

3. Manmeet Kaur

4. Richa Phutela

\section{PARTICULARS OF CONTRIBUTORS:}

1. Associate Professor, Department of Pathology, Guru Gobind Singh Medical College, Faridkot.

2. Associate Professor, Department of Pathology, Guru Gobind Singh Medical College, Faridkot.

3. Assistant Professor, Department of Pathology, Guru Gobind Singh Medical College, Faridkot.

4. Junior Resident, Department of Pathology, Guru Gobind Singh Medical College, Faridkot.

\section{NAME ADDRESS EMAIL ID OF THE CORRESPONDING AUTHOR:}

Dr. Kanwardeep Kaur Tiwana,

H. No. 75, Medical College Campus, Sadiq Road,

Guru Gobind Singh Medical College, Faridkot- 151203, Punjab.

E-mail: kanwardeepjhajj@gmail.com

Date of Submission: 03/04/2014. Date of Peer Review: 04/04/2014.

Date of Acceptance: 16/04/2014.

Date of Publishing: 28/04/2014. 